\title{
Antiperoxidative properties of oil mixes of high ratio Omega-9:Omega-6 and low ratio Omega-6:Omega-3 after molar extraction in rats ${ }^{1}$
}

\author{
Radamés Bezerra MeloI, Sérgio Botelho Guimarães ${ }^{\mathrm{II}}$, Paulo Goberlânio de Barros Silva ${ }^{\mathrm{III}}$, Reinaldo Barreto Oriá ${ }^{\mathrm{IV}}$, José Ulisses \\ de Souza Melov, Paulo Roberto Leitão Vasconcelos ${ }^{\mathrm{VI}}$
}

DOI: http://dx.doi.org/10.1590/S0102-86502014000600004

${ }^{\mathrm{I}}$ Fellow Master degree, Postgraduate Program in Surgery, Department of Surgery, Federal University of Ceara (UFC), Fortaleza-CE, Brazil. Conception of the study, technical procedures, acquisition of data, manuscript writing.

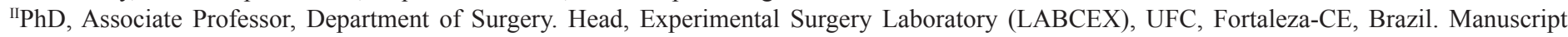
writing, critical revision.

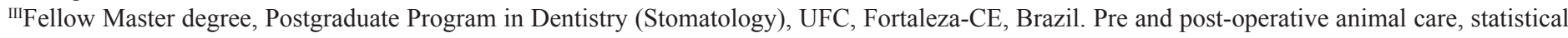
analysis.

${ }^{\text {IV }} \mathrm{PhD}$, Associate Professor, Department of Morphology. Head, LABICONTE, UFC, Fortaleza-CE, Brazil. Conception and design of the study, critical revision.

vPhD, Associate Professor, Department of Surgery, UFC, Fortaleza-CE, Brazil. Critical revision.

${ }^{v} \mathrm{PhD}$, Full Professor, Coordinator, Postgraduate Program in Surgery, Department of Surgery, UFC, Fortaleza-CE, Brazil. Conception, design, intellectual and scientific content of the study; critical analysis, final approval of the manuscript.

\section{ABSTRACT}

PURPOSE: To evaluate the antioxidant and antiperoxidative effects of oil mixes of high ratio Omega-9:Omega-6 and low ratio Omega6:Omega-3 in the third day after tooth extraction in rats.

METHODS: Thirty-two male Wistar rats $(270-310 \mathrm{~g})$ were randomly distributed in two groups: Control $(\mathrm{n}=24)$ and Test $(\mathrm{n}=8)$. Control group was divided into three subgroups ( $\mathrm{n}=8$ ): $\mathrm{G} 1$ : Sham-Saline; $\mathrm{G} 2$ : Saline; G3: Isolipid. G1 and G2 animals received $\mathrm{NaCl} 0.9 \%$ while G3 rats were treated with an isolipid mixture (alpha-linolenic acid - ALA) containing -6/-3 oils (8:1 ratio) and-9/-6 (0.4:1 ratio). Test group animals (G4) received oily mixtures (alpha-linolenic acid - ALA, docosahexaenoic acid - DHA, eicosapentaenoic acid - EPA) of -6/-3 (1.4:1 ratio) and -9/-6 (3.4:1 ratio). Saline and oils were administered by gavage during four days before and three days after first mandibular molar extraction. Following, samples (arterial blood and alveolar mucosa) were collected for glutathione (GSH) and thiobarbituric acid reactive substances (TBARS) assays.

RESULTS: Oil mixes induced a significant decrease in GSH and TBARS tissue and plasma concentrations in the third day post-surgery. CONCLUSION: Gavage administration of oil mixes of high ratio Omega-9:Omega-6 and low ratio Omega-6:Omega-3 after molar extraction in rats induces a significant decrease in lipid peroxidation.

Key words: Fatty Acids, Omega-3. Fatty Acids, Omega-6. Lipid Peroxidation. Tooth Extraction. Rats. 


\section{Introduction}

Oxidative stress can be defined as imbalance between production and collection of reactive oxygen species (ROS). The oral supplementation of antioxidants is well indicated in several situations, such as cancer, sepsis, preoperative of major surgeries and malnourished or critically ill patients ${ }^{1}$. The omega-3 is one of the most used in research immunonutrients ${ }^{2}$.

Currently, the adequacy of the balance of dietary lipids has motivated numerous investigations. In patients with changes in metabolic responses, the balance between dietary lipids aims to control oxidative stress and increased inflammatory response, through the relationship between the types of polyunsaturated fatty acids ingested ${ }^{3}$, affecting the synthesis of eicosanoids that act as intermediate messengers of growth factors controlling the growth and differentiation of epithelial cells ${ }^{4}$.

Protective effects of oils mixes against ischemia/ reperfusion injury have been demonstrated. Pinheiro et al. ${ }^{5}$ investigated the effects of pre-conditioning with mixtures of oils containing high and low ratio $\omega-6 / \omega-3$ and $\omega-9 / \omega-6$ relationship in an experimental model and concluded that these oil combinations protects brain neurons against ischemiareperfusion injury. The data found in the literature vary widely as to the best combination of antioxidants, the dosage, route of administration, the levels to be ideally achieved, the best time and how long they have to be administered in order to provide an effective protection against the oxidative injury. Despite the fact that there is no consensus regarding those topics, an early study has recommended that therapy should be instituted before the establishment of oxidative injury ${ }^{6}$.

The hypothesis of this study is that the use of combinations containing different proportions of omega 3,6 and 9 amino acids may have a noticeable antioxidant effect during the inflammatory phase of the wound healing after dental extraction.

\section{Methods}

Approval for experimental use of laboratory animals was obtained from the local Ethics Committee on Animal Use (CEUA, former CEPA) (protocol 73/2011, February 29, 2012)) and is in compliance with the Federal Law No. 11794 of October 8, 2008, and the Decree $n^{\circ}$ 6,689, July 15, 2009 that regulated the law in 11,794, available from http: www.planalto.gov.brccivil03Ato200720102008LeiL11794.htm. The study was designed to minimize the number of animals required for the experiments.

\section{Study design}

Wistar rats provided by the Faculty of Medicine Small Animals Breeding Facility (UFC) In this controlled experimental study, after one week of acclimatization, 32 male Wistar rats provided by the Faculty of Medicine Small Animals Breeding Facility (UFC), weighing 270-310g, were randomly distributed in two groups: Control $(n=24)$ and Test $(n=8)$. Control group was divided into three subgroups $(n=8)$ as follows: G1: Sham-Saline; G2: Saline; G3: Isolipid. G1 and G2 animals received $\mathrm{NaCl} 0,9 \%$ while $\mathrm{G} 3$ rats were treated with an isolipid mixture (alpha-linolenic acid - ALA) containing $-6 /-3$ oils (8:1 ratio) and -9/-6 (0.4:1 ratio), by gavage for four days before and three days after surgical procedure. Test group animals (G4) received oily mixtures (alpha-linolenic acid ALA, docosahexaenoic acid - DHA, eicosapentaenoic acid EPA) of -6/-3 (1.4:1 ratio) and -9/-6 (3.4:1 ratio). Saline and oils were administered by gavage during four days before and tree days after first mandibular molar extraction? ${ }^{7}$ Isolipid and Mix preparations are detailed on Table 1.

TABLE 1 - Composition of isolipid and oil mixes preparations.

\begin{tabular}{|c|c|c|c|}
\hline & Composition & Source $\omega-3$ & Ratio \\
\hline \multirow[t]{4}{*}{ Isolipid } & $\omega-6+\omega-3$ & & \\
\hline & & & $\omega-6: \omega-3=8: 1$ \\
\hline & Corn oil & ALA & \\
\hline & Soybean oil & & $\omega-9: \omega-6=0,3: 1$ \\
\hline \multirow[t]{3}{*}{ Test oil mixes } & $\omega-9+\omega-6+\omega-3$ & $\operatorname{ALA}(35 \%)$ & \\
\hline & & EPA $(39 \%)$ & $\omega-6: \omega-3=1,4: 1$ \\
\hline & $\begin{array}{l}\text { Olive oil } \\
\text { Canola oil } \\
\text { Fish oil }\end{array}$ & DHA $(26 \%)$ & $\omega-9: \omega-6=3,7: 1$ \\
\hline
\end{tabular}


On the third day, G1 and G2 rats, anesthetized with a fresh-prepared mixture of ketamine $90 \mathrm{mg} \cdot \mathrm{kg}^{-1}+$ xylazine $10 \mathrm{mg} . \mathrm{kg}^{-1}$ injected intramuscularly, underwent a surgical molar extraction. G1 animals underwent sham operation. Rats were kept under controlled environmental conditions $\left(24^{\circ} \mathrm{C}\right.$ relative humidity $40 \%-60 \%$, 12-hour alternate light-dark cycles, food and water ad libitum).

Samples (arterial blood and alveolar mucosa) were collected on the third post-operative and the animals were killed by cervical dislocation at the end of the experiment.

\section{Laboratory parameters}

Thiobarbituric acid reactive substances (TBARS) and glutathione (GSH) concentrations were assayed to evaluate the oxidative stress, using methods described in the literature. Lipid peroxidation was assayed by measuring malondialdehyde as TBAreactive substances ${ }^{8}$. GSH levels were estimated by the method of Sedlak and Lindsay ${ }^{9}$.
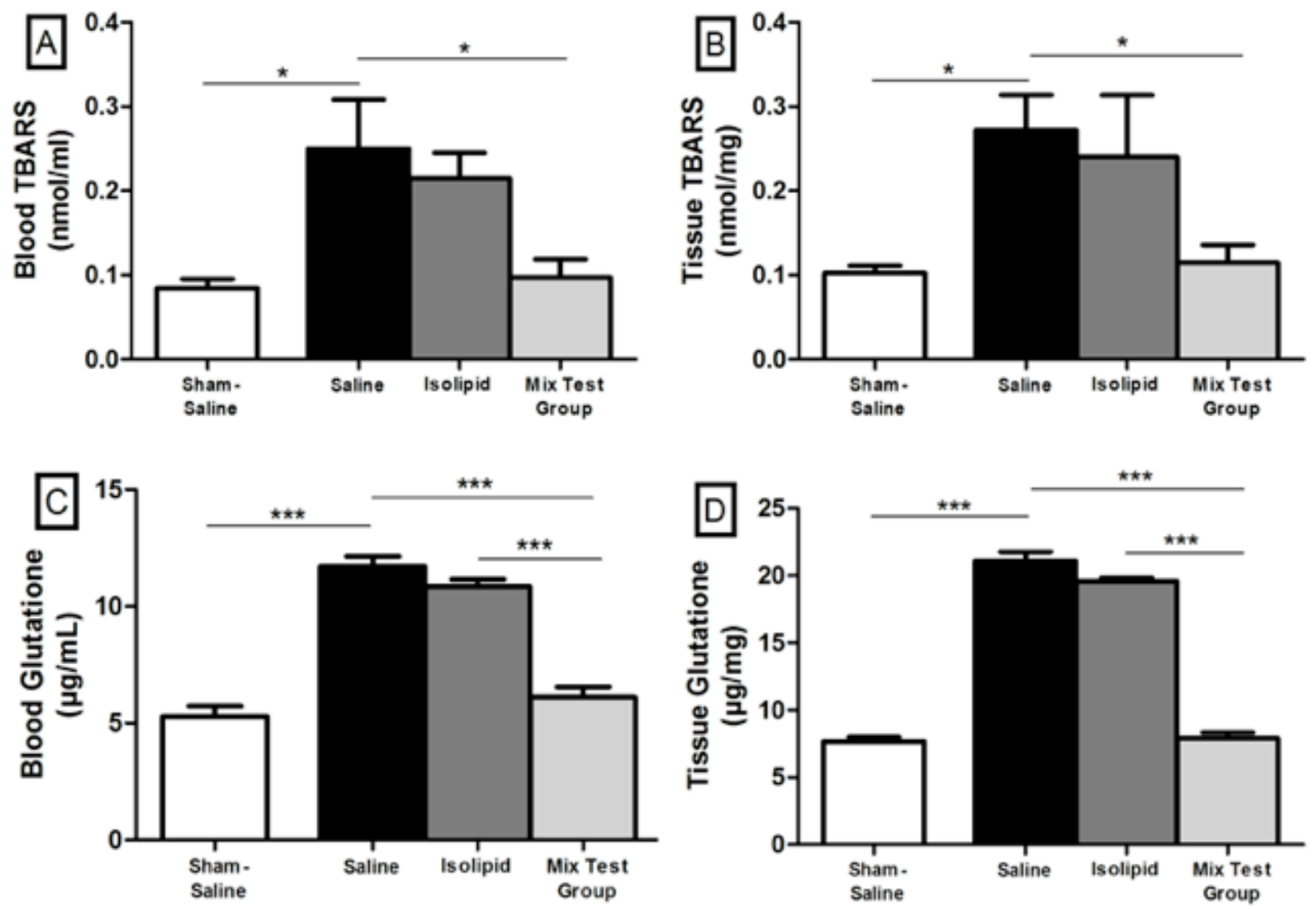

FIGURE 1 - Thiobarbituric acid reactive substances (TBARS) levels in blood (A) and local tissue (B); Glutathione (GSH) levels in blood (C) and local tissue (D) three days post dental extraction. ${ }^{*} \mathrm{p}<0.05$; $* * * \mathrm{p}<0.001$; Test ANOVA/Tukey. 


\section{GSH Assay}

There was a significant reduction in GSH blood levels in G4 animals treated with oil mixes $(10.84 \pm 00: 32$ vs.6:10 \pm $0: 45, \mathrm{p}<0.001)$ compared with the group treated with Isolipid mix and with the group treated with saline (12:46 \pm 00:24 vs.6:10 $\pm 0: 45, \mathrm{p}<0.001$ ) (Figure 1C). However, GSH blood and tissue concentrations increased significantly $(p<0.001)$ in rats treated with saline, compared with animals submitted to a simulated (sham) procedure (Figure 1C/D). There were significant reductions in tissue GSH levels in animals treated with test oil mixes compared with saline group $(21.10 \pm 0.69$ vs. $12: 42 \pm 7.90, \mathrm{p}<0.001)$ and isolipidic $\operatorname{mix}(21.10 \pm 0.69$ vs.19:58 $\pm 12: 27, \mathrm{p}<0.001)$ (Figure 1C/D).

\section{Discussion}

Research studies concerning the relationship between the repair and the possible factors that affect the healing process after tooth extraction in rats were initiated in early $1923^{10-11}$. The healing process post dental extraction has been studied in several animal models, and its sequence is relatively understood and divided into three phases: (a) initial phase: inflammatory between one and five days, (b) middle phase: during bone formation five to 20 days, (c) final phase: bone remodeling phase from 20 to 60 days ${ }^{12}$. Local and systemic factors may affect rat socket healing, including salivary gland hypofunction, osteoporosis, osteopetrosis, diabetes mellitus and treatment with calcitonin or cortisone $\mathrm{e}^{12-17}$. In this work it was found that oil mixes administered by gavage before and after dental extraction may provide protection from lipid peroxidation in the third post-operative day. (Figure 1)

Fatty acids are used in a selective synthesis of phospholipids of cell membranes and their organelles. Essential fatty acids can determine structural and functional alterations of membrane phospholipids, including cells of the immune system, modifying its permeability, activity of receptors and enzymes, transport, regulatory functions and cellular metabolism ${ }^{18}$. Moreover, activate intracellular signaling routes for the formation of biologically active molecules that act as second messengers. Thus, may interfere with physiological events related to hemodynamic ${ }^{19}$, oxygenation $^{20}$, inflammation ${ }^{21}$ and organic defense ${ }^{22}$.

Omega-9 (oleic acid) confer protection against lipid peroxidation of different polyunsaturated fatty acids such as linolenic acid, EPA, DHA containing 4, 5 and 6 double bonds respectively and because that are much less stable. The use of compositions rich in monounsaturated lipids as compared to the use of polyunsaturated showed low inflammatory response and low production of free radicals rich in monounsaturated formula. Membranes that are rich in monounsaturated fatty acids (MUFA) are less susceptible to oxidation by free radicals that membranes rich in saturated fatty acids, presumably because the greater number of unsaturations increase the likelihood of double bonds than in reactive oxygen species ${ }^{23}$. This may explain the antiperoxidative protection of oil mixes test shown in Figure 1A and 1B.

Olive oil is rich in $\omega-9$ fatty acids and vitamin $\mathrm{E}$ and is known for its antioxidant properties. The fact that the molecular structure of oleic acid have only one double bond, together with the presence of vitamin $\mathrm{E}$ confers greater protection against lipid peroxidation. Antioxidants decrease the accumulation of $\operatorname{ROS}^{24}$, which can reduce local tissue damage and accelerate the healing process ${ }^{25}$.

In this study, the use of an oil mix containing alpha-linolenic acid - ALA, docosahexaenoic acid - DHA, eicosapentaenoic acid - EPA of -6/-3 (1.4:1 ratio) and -9/-6 (3.4:1 ratio) promoted a decrease in GSH levels, an issue showing that GSH becomes "lesser necessary" and, in this way, an antioxidant action. Generally, cells react to oxidative stress with a increase in GSH pool as part of their adaptative answer to the potential oxidative lesion..$^{20}$ Therefore, a lower GSH level indicates a less aggressive potential oxidative stress.

\section{Conclusion}

This study shows the antiperoxidative effects of oil mixes containing alpha-linolenic acid - ALA, docosahexaenoic acid DHA, eicosapentaenoic acid - EPA of -6/-3 (1.4:1 ratio) and -9/-6 (3.4:1 ratio) acids when administered by gavage before and after rat tooth extraction.

\section{References}

1. Grimble RF. Immunonutrition. Curr Opin Gastroenterol. 2005 Mar;21(2):216-22 PubMed PMID: 15711216.

2. Stableforth WD, Thomas S, Lewis SJ. A systematic review of the role of immunonutrition in patients undergoing surgery for head and neck cancer. Int J Oral Maxillofac Surg. 2009 Feb;38(2):103-10. doi: 10.1016/j.ijom.2008.12.008.

3. Calder PC. Long-chain n-3 fatty acids and inflammation: potential application in surgical and trauma patients. Braz J Med Biol Res 2003 Apr;36(4):433-46 PubMed PMID: 12700820.

4. Capone SL, Bagga D, Glaspy JA. Relationship between omega-3 and omega-6 fatty acid ratios and breast cancer. Nutrition. 1997;13(9):822-4 PubMed PMID: 9290101.

5. Pinheiro PM, Campelo AP, Guimarães SB, Patrocínio RM, Valença Junior JT, Vasconcelos PR. Preconditioning with oil mixes of high ratio Omega-9: Omega-6 and a low ratio Omega-6:Omega-3 in rats subjected to brain ischemia/reperfusion. Acta Cir Bras. 2011;26 Suppl 1:32-7. PubMed PMID: 21971654.

6. Silva HC, Coletta RD, Jorge J, Bolzani G, Almeida OP, Graner E. The 
effect of cyclosporin A on the activity of matrix metalloproteinases during the healing of rat molar extraction wounds. Arch Oral Biol. 2001 Sep;46(9):875-9. PubMed PMID: 11420061.

7. Pires VL, Souza JR, Guimarães SB, Silva Filho AR, Garcia JH, Vasconcelos PR. Preconditioning with L-alanyl-L-glutamine in a Mongolian gerbil model of acute cerebral ischemia/reperfusion injury. Acta Cir Bras. 2011;26 Suppl 1:14-20. PubMed PMID: 21971651.

8. Uchiyama M, Mihara M: Determination of malondialdehyde precursor in tissues by thiobarbituric acid test. Anal Biochem. 1978 May;86(1):271-8. PubMed PMID: 655387.

9. Sedlak J, Lindsay RH: Estimation of total, protein-bound, and nonprotein sulfhydryl groups in tissue with Ellman's reagent. Anal Biochem. 1968 Oct;24;25(1):192-205. PubMed PMID: 4973948.

10. Maahs MP, Azambuja AA, Campos MM, Salum FG, Cherubini K. Association between bisphosphonates and jaw osteonecrosis: a study in Wistar rats. Head Neck. 2011 Feb;33(2):199-207. doi: 10.1002/hed.21422.

11. Bodner L, Kaffe I, Littner MM, Cohen J. Extraction site healing in rats. A radiologic densitometric study. Oral Surg Oral Med Oral Pathol. 1993 Mar;75(3):367-72. PubMed PMID: 8469551.

12. Smales RJ. Effects of systemic cortisone on healing of tooth sockets in rats. A histologic study. Oral Surg Oral Med Oral Pathol. 1978 May;45(5):685-8. PubMed PMID: 276785.

13. Ubios AM, Jares Furno G, Guglielmotti MB. Effect of calcitonin on alveolar wound healing. J Oral Pathol Med. 1991 Aug;20(7):322-4. PubMed PMID: 1895250.

14. Dayan D, Bodner L, Horowitz I. Effect of salivary gland hypofunction on the healing of extraction wounds: a histomorphometric study in rats. J Oral Maxillofac Surg. 1992 Apr;50(4):354-8. PubMed PMID: 1545290.

15. Devlin H, Garland H, Sloan P. Healing of tooth extraction sockets in experimental diabetes mellitus. J Oral Maxilofac Surg. 1996 Sep;54(9):1087-91. PubMed PMID: 8811819.

16. Shimizu M, Furuya R, Kawawa T, Sasaki T. Bone wound healing after maxillary molar extraction in ovariectomized aged rats: quantitative backscattered electron image analysis. Anat Rec. 2000 May;259(1):76-85. PubMed PMID: 10760746.

17. Calder PC, Deckelbaum RJ. Dietary lipids: more than just a source of calories. Curr Opin Clin Nutr Metab Care. 1999 Mar;2(2):105-7. PubMed PMID: 10453339.

18. Calder PC, Grimble RF. Polyunsaturated fatty acids, inflammation and immunity. Eur J Clin Nutr. 2002 Aug;56 Suppl 3:S14-9. PubMed PMID: 12142955.

19. Pinheiro PM, Campelo AP, Guimarães SB, Patrocínio RM, Valença Junior JT, Vasconcelos PR. reconditioning with oil mixes of high ratio Omega-9: Omega-6 and a lowratio Omega-6:Omega-3 in rats subjected to brain ischemia/ reperfusion. Acta Cir Bras. 2011;26 Suppl 1:32-7. PubMed PMID: 21971654 .
20. Melo JUS, Santos JM, Kimura Ode S, Campos Júnior MM, Melo RB, Vasconcelos PR. Effects of fatty acids on liver regeneration in rats. Rev Col Bras Cir. 2010 Oct;37(5):351-7. PubMed PMID: 21181001.

21. Grimble RF. Dietary manipulation of the inflammatory response. Proc Nutr Soc. 1992 Aug;51(2):285-94. PubMed PMID: 1438337.

22. Johnston PV. Dietary fat, eicosanoids, and immunity. Adv Lipid Res. 1985;21:103-41. PubMed PMID: 3895844.

23. Oh YT, Lee JY, Lee J, Kim H, Yoon KS, Choe W, Kang I. Oleic acid reduces lipopolysaccharide-induced expression of iNOS and COX2 in BV2 murine microglial cells: possible involvement of reactive oxygen species, p38 MAPK, and IKK/NF-kappaB signaling pathways. Neurosci Lett. 2009 Oct 23;464(2):93-7. doi: 10.1016/j. neulet.2009.08.040.

24. Luo JD, Wang YY, Fu WL, Wu J, Chen AF. Gene Therapy of endothelial nitric oxide synthase and manganese superoxide dismutase restores delayed wound healing in type 1 diabetic mice. Circulation. 2004 Oct;19;110(16):2484-93. PubMed PMID: 15262829.

25. Niemoller TD, Bazan NG. Docosahexaenoic acid neurolipidomics. Prostaglandins Other Lipid Mediat. 2010 Apr;91(3-4):85-9. doi: 10.1016/j.prostaglandins.2009.09.005.

\section{Correspondence:}

Prof. Paulo Roberto Leitão de Vasconcelos Rua Professor Costa Mendes, 1608/3 andar 60430-140 Fortaleza - CE Brasil

Tel.: (55 85)3366-8083

Fax: (55 85)3366-8064

paulo.vasconcelos@ufc.br

Received: Jan 16, 2014

Review: March 18, 2014

Accepted: April 22, 2014

Conflict of interest: none

Financial source: Coordination of Improvement for Higher Academic Staff (CAPES)

${ }^{1}$ Research performed at Experimental Surgery Laboratory (LABCEX), Faculty of Medicine, Federal University of Ceara (UFC), Fortaleza-CE, Brazil. Part of Master degree thesis, Postgraduate Program in Surgery, UFC. Tutor: Prof. Paulo Roberto Leitao Vasconcelos. 